\title{
Xylocythere sarrazinae, a new cytherurid ostracod (Crustacea) from a hydrothermal vent field on the Juan de Fuca Ridge, northeast Pacific Ocean, and its phylogenetic position within Cytheroidea
}

\author{
Tanaka Hayato ${ }^{1,{ }^{*}}$, Lelièvre Yann ${ }^{2,3}$, Yasuhara Moriaki ${ }^{4}$
}

1 Tokyo Sea Life ParkTokyo, Japan

2 Ifremer Centre de Bretagne, REM/EEP, Laboratoire Environnement ProfondPlouzane, France

3 Département de Sciences BiologiquesUniversité de MontréalMontreal, Canada

${ }^{4}$ School of Biological Sciences and Swire Institute of Marine ScienceThe University of Hong KongHong Kong, China

*Corresponding author : Hayato Tanaka, email address : Cladocopina@gmail.com

\begin{abstract}
:
This paper described Xylocythere sarrazinae sp. nov. (Ostracoda: Cytheroidea: Cytheruridae: Eucytherurinae), collected at $2196 \mathrm{~m}$ depth from the Grotto hydrothermal edifice (Main Endeavor Field, Juan de Fuca Ridge) in the northeastern Pacific Ocean. This new species was found living in association with Ridgeia piscesae tubeworm assemblages. It is the second representative of Xylocythere described from such vents. Xylocythere sarrazinae sp. nov. is easily distinguished from the seven described species of Xylocythere by the surface ornamentations of its carapace, with the most similar species to it being Xylocythere pointillissima Maddocks \& Steineck, 1987. However, Xylocythere sarrazinae sp. nov can be distinguished from $X$. pointillissima based on the following characters: having a subsquare basal capsule outline, a spatulate upper ramus, a flattened distal lobe of the male copulatory organ, and having 15 maxillula branchial plate setae. We found that one specimen of this new species had multiple spherical objects associated with the internal openings of its pore clusters. These objects were quite similar in shape to that of chemoautotrophic bacteria, which were previously reported from the outer surfaces of pore clusters in other Xylocythere species. Finally, we provided a preliminary phylogenetic analysis of this new species based on 18S rRNA gene sequences to determine the phylogenetic position of the subfamily Eucytherurinae within the superfamily Cytheroidea. This analysis revealed that Xylocythere (Eucytherurinae) may be the most ancestral lineage among the Cytheruridae and identified paraphyletic relationships among the three subfamilies within Cytheruridae. This result supported certain previous studies' conclusions based on morphology and fossil records.
\end{abstract}

Keywords : Chemosynthetic habitat, Crustacea, Eucytherurinae, Meiofauna, Pore clusters 
4 Ostracods are tiny crustaceans covered by a calcified carapace with two valves. They are important representatives of the

5 meiofaunal compartment. They occur in a wide variety of aquatic environments including deep-sea chemosynthetic

6 habitats. According to a recent review on living and fossil ostracods from chemosynthetic ecosystems (Karanovic and

7 Brandão 2015), most deep-sea species have been described from the eastern Pacific Ocean (Kornicker 1991; Kornicker

8 and Harrison-Nelson 2005; Maddocks 2005). Additionally, several species left in open nomenclature have been reported

9 from the equatorial Pacific and northern Atlantic oceans (van Harten 1992, 1993; Degen et al. 2012; Zeppilli and

10 Danovaro 2012). Recently, the first ostracod species from hydrothermal vents in the western Pacific Ocean was described

11 by Tanaka and Yasuhara (2016). Regardless of their recent distribution, fossil records of vent ostracods trace back to the

12 middle Devonian (Olempska and Belka 2010).

14 In this paper, we describe a new ostracod species belonging to the genus Xylocythere (Maddocks and Steineck, 1987) that

15 was recently discovered on the Juan de Fuca Ridge, northeastern Pacific. The type species of this genus, Xylocythere

16 turnerae Maddocks and Steineck, 1987, was collected from deep-sea experimental wood falls at approximately $3500 \mathrm{~m}$

17 depth deployed on the southeast of Woods Hole, Massachusetts (USA). Simultaneously, three other Xylocythere species

18 were also described from the Tongue of the Ocean (Bahamas), off Sainte Croix (Virgin Islands) and from the Panama

19 basin (Maddocks and Steineck 1987) (see Fig. 1 and Table 1). Five years later, van Harten (1992) discovered a 
1 Xylocythere species from a vent field of the East Pacific Rise and discussed the relationships between deep-sea wood-

2 island habitats and vent fauna with regard to their distribution and trophic ecology. Subsequently, this species was

3 formally described as Xylocythere vanharteni based on newly collected specimens (Maddocks 2005). Thus, five living

4 Xylocythere species are known and all of them are endemic to chemosynthetic habitats. Additionally, two fossil species

5 are known, namely Xylocythere producta (Colalongo and Pasini, 1980), from the Middle Miocene to the Early

6 Pleistocene (Colalongo and Pasini 1980; Dall'Antonia 2003), and Xylocythere carpathica Szczechura, 1995, from the

Middle Miocene (Szczechura 1995, 2000). Several unnamed fossil species of Xylocythere were also reported from the

Late Eocene to the Holocene (Steineck et al. 1990; Corrège 1993; Kiel and Goedert 2006; Bergue and Coimbra 2008;

Yasuhara et al. 2009; Machian-Castillo et al. 2014). Notably, the oldest Xylocythere fossil (Late Eocene) was recorded as

a member of wood-fall assemblages (Kiel and Goedert 2006). Their wide geographical distribution and bathymetric

range (Fig. 1 and Table 1) imply ancient origins. This study describes a new Xylocythere species based on the

morphology of the carapace and soft parts. This is the second representative of Xylocythere coming from an hydrothermal

vent field. The objective of this study is to provide the detailed morphological description of this new species of

Xylocythere, which was found at $2196 \mathrm{~m}$ depth on the Grotto hydrothermal edifice located on the Juan de Fuca ridge

northeast Pacific. The new species was found living in association with Ridgeia piscesae tubeworm assemblages, in areas

of low fluid emissions. We also provide a preliminary phylogenetic analysis of this new species based on nearly complete 
The $90 \mathrm{~km}$ Endeavour segment, located on the northern part of the Juan de Fuca Ridge (JdFR), is a hydrothermally active region harboring five major hydrothermal vent fields (Kelley et al. 2012). Among these, the Main Endeavour Field (MEF) (Fig. 2) includes Grotto (47.949292N, 129.098433W), a $10 \mathrm{~m}$ high active hydrothermal sulfide vent cluster located at a depth of $2196 \mathrm{~m}$. This large complex covers a surface area of $450 \mathrm{~m}^{2}$, and forms a cove with an opening to the north (Xu et al. 2014). Located in the Endeavour Hydrothermal Vent Marine Protected Area (MPA), this site was selected as a target for sensor deployment as part of the cabled deep-sea observatory of Ocean Networks Canada (ONC) to study and monitor the temporal dynamics of deep-sea vent ecosystems. Like many other sulfide structures within the MEF, Grotto is colonized by a mosaic of faunal assemblages (Sarrazin et al. 1997), including the low-flow assemblages of the tubeworm Ridgeia piscesae Jones, 1985 and their associated fauna.

\section{Sampling}

14 The Ocean Networks Canada Expedition 2015: Wiring the Abyss cruise was conducted from aboard the R/V Thomas G.

15 Thompson vessel with the Remotely Operated Vehicle (ROV) Jason from August 25 to September 14 2015. The

16 specimens of ostracods examined were collected on September 7 2015, within two samples of R. piscesae tubeworms

17 taken from the Grotto edifice. The locations of the two samples were as follows: dive J0831-S1

18 (47.949292N, 129.098433W, $2196 \mathrm{~m}$ depth) and dive J0831-S3 (47.949302N, 129.098491W, $2196 \mathrm{~m}$ depth). Details of

19 the sampling methods used can be found in Lelièvre et al. (2018). After bringing the faunal samples aboard, the 

siboglinid tubeworm assemblages were washed over stacked sieves (with $250 \mu \mathrm{m}, 63 \mu \mathrm{m}$, and $20 \mu \mathrm{m}$ mesh sizes).

2 Ostracod specimens were picked out from the remnants in the $250 \mu \mathrm{m}$ sieves and preserved in $96 \%$ ethanol. A total of 35

3 individuals of Xylocythere were randomly extracted from the two samples (dive J0831-S1 and -S3) and examined for the

4 present taxonomic study. The remaining ostracod specimens were used in isotopic analyses and biodiversity studies

5 (Lelièvre et al. 2018).

\section{Morphology}

The collected ostracod specimens were fixed in $96 \%$ ethanol and preserved at room temperature for description and DNA extraction. The soft parts were separated from the valves and dissected using fine needles under a stereo-binocular microscope (SZH 10, OLYMPUS). The valves were preserved on a cardboard cell slide and the soft parts mounted in a

11 gum-chloral medium, Neo-Shigaral (Shiga Konchu Fukyusha, Japan), on glass slides. The specimens were then observed and sketched using a transmitted-light binocular microscope (BX 50, OLYMPUS) with a differential interference contrast system and a camera Lucida. The valves were washed with distilled water and gold-coated by an Ion sputtering device (JFC-1100, JEOL). The valves were then observed by scanning electron microscopy (SEM; JSM-5600LV, JEOL). The type series was deposited in the collection of the University Museum, The University of Tokyo (UMUT) with the prefix 
Total DNA extraction from holotype (UMUT RA32930) was performed using the DNeasy Blood and Tissue Kit (Qiagen,

2 USA) following the manufacturer's protocol. Morphological voucher was prepared following by Tanaka and Ohtsuka

3 (2016) and deposited in the UMUT.

Nearly complete sequence of the nuclear 18S rRNA gene was PCR amplified using the eukaryotic primers

(Moon-van der Staay et al. 2000). The $25 \mu 1$ reaction contained $0.125 \mu$ of TaKaRa Ex Taq HS (TAKARA BIO Inc.,

Japan), $2.5 \mu \mathrm{l}$ of 10×Ex Taq buffer, $2 \mu \mathrm{l}$ of dNTP mix, $1 \mu \mathrm{l}$ of each primer ( 5 pmoles each), $5 \mu 1$ of template DNA, and

$13.375 \mu \mathrm{l}$ sterilized distilled water. The PCR protocol consisted of an initial denaturation step at $95{ }^{\circ} \mathrm{C}$ for $2 \mathrm{~min}$,

followed by 40 cycles of denaturation at $98{ }^{\circ} \mathrm{C}$ for $10 \mathrm{~s}$, annealing at $52{ }^{\circ} \mathrm{C}$ for $30 \mathrm{~s}$, extension at $72{ }^{\circ} \mathrm{C}$ for $2 \mathrm{~min}$, and a

9 final extension at $72{ }^{\circ} \mathrm{C}$ for $10 \mathrm{~min}$. Quantity and length of the PCR products were checked by $1 \%$ agarose S (Nippon

10 Gene, Japan) gel electrophoresis and stained with ethidium bromide. The products were purified for sequencing using a

11 FastGene Gel/PCR Extraction Kit (NIPPON Genetics Co, Ltd, Japan), according to the manufacturer's protocol.

12 Sequencing was performed by the Macrogen Japan Corp. (Tokyo, Japan) with the same primers as those used for PCR

13 amplification.

14

15 Sequence analysis and phylogenetic reconstruction

16 A homology search of 18S rDNA sequence was performed by BLAST (Altschul et al. 1990, 1997) with the megablast

program from the National Center for Biotechnology Information (NCBI, http://blast.ncbi.nlm.nih.gov/Blast.cgi). All of

already existing 44 sequences of 18S rRNA gene of superfamily Cytheroidea Baird, 1850 and two outgroup sequences 

sequences were aligned with MAFFT v. 7.310 (Katoh et al. 2002, 2005; Katoh and Standley 2013) using the L-INS-i algorithm. The ambiguous regions of the aligned sequences were detected and deleted using GBLOCKS 0.91b

4 (Castresana 2000). Phylogenetic analyses were performed with the maximum likelihood (ML) and Bayesian inference (BI) methods using in PhyML v. 3.0 (Guindon and Gascuel 2003; Guindon et al. 2010) and MrBayes v. 3.2.2 (Ronquist and Huelsenbeck 2003), respectively. The jModelTest v. 2.1 (Darriba et al. 2012) for ML and MrModeltest v. 2.3 (Nylander 2004) for BI were used to find the best-fit evolutionary model for the present data set under the Akaike information criterion (AIC, Akaike 1974). For ML, the bootstrap values (Felsenstein 1985) were calculated with 1000 replications. For the BI method, four Markov chains were run for 1,000,000 generations, and were sampled every 100 generations. The convergence was assessed by using Tracer v1.6 (Rambaut et al. 2014). The first 2,500 samples from each run were discarded as burn-ins.

\section{Results}

\section{Taxonomy}


(Figs 4-9)

Material examined. Holotype: adult male (UMUT RA32930), right valve length without anterior spines $548 \mu \mathrm{m}$, height

$247 \mu \mathrm{m}$, left valve length $556 \mu \mathrm{m}$, height $254 \mu \mathrm{m}$, soft parts mounted on a glass slide and valves preserved in a

Type locality. The holotype specimen and the paratypes were collected from the Grotto edifice of the Juan de Fuca Ridge, northeast Pacific (dive J0831-S1; 47.949292, -129.098433; depth 2196 m).

\section{Diagnosis.}

14 Carapace, elongate-ovoid. Surface nearly smooth and covered with numerous pore clusters. Two wedge-shaped denticles

\section{Description.}


2 Carapace (Figs 4; 5a-d, g; 6). Size difference in length and height between left and right valves inconspicuous (Table 2).

3 Both left and right valves of male slightly smaller than valves of female (Table 2; Fig 3). Elongate-ovoid outline, no

4 conspicuous caudal process. Surface nearly smooth and covered with numerous pore clusters (Fig. 5a, b). Simple

5 sensillum pores with rims locating on anterior and posterior region and without rims locating within muri. A prominent,

6 posteriorly-directed postero-ventral spine present on the lateral surface of each valve (Figs 4; 5a, b). Two wedge-shaped

7 denticles present at mid-height on the anterior margin of each valve (Fig. 5a). In dorsal view, carapace elongated-ovate with greatest thickness located slightly behind mid-length. Marginal infold broad (Fig. 5c, d). In interior view, numerous pore clusters visible (Fig. 5c, d). Adductor muscle scars four in vertical row (Figs 4; 6h). Hingement modified merodontentomodont (Fig. 6a, b); left valve with deep sockets as anterior and posterior elements (Fig. 6c, e); right valve with

11 kidney-shaped prominent terminal teeth as anterior and posterior elements (Fig. 6d, f); several crenulations developing at both ends of the median elements (Fig. 6c-f); middle part of median elements smooth bar. Antennula (Fig. 7a). Six articulated podomeres, slender. First podomere bare. Second podomere with one seta on middle of posterior margin and setulae on anterior margin. Third podomere with one setulous seta on antero-distal end and setulae on anterior margin. Fourth podomere with two setae on antero-distal end and one seta on postero-distal end. Fifth podomere with three setae on antero-distal end and one seta on postero-distal end. Sixth podomere with two setae and one blunt tipped seta (aestetasc) on distal end. Antenna (Fig. 7b). Five articulated podomeres. First podomere (basis) with one long four-segmented exopodite (spinneret seta). Second (first endopodite) podomere with two setae on postero-distal end. Third (second endopodite) 

podomere with two setae on posterior end. Fourth podomere (third endopodite) with one slender spatulate seta on lateral surface of proximal part, one seta in middle of anterior margin, and one short stout seta on postero-distal part. Fifth

3 (fourth endopodite) podomere with one short simple postero-distal seta and one stout distal claw. Mandibula (Fig. 7c-e). Coxa with one long setulous dorsal seta. Coxal endite consisting of eight teeth (Fig.

7e). Palp consisting of four podomeres. First podomere (basis) with one long seta (exopodite) near proximal end and one long seta on ventro-distal end (Fig. 7d). Second podomere (first endopodite) with three setae ventro-distal end. Third podomere (second endopodite) with two setae on ventro-distal end and four setae on dorsal middle margin. Fourth podomere (third endopodite) with two setae on distal end. Maxillula (Fig. 7f-j). Branchial plate (exopodite) with 15 plumose setae and two reflexed setae (Fig. 7f). Basal podomere with one palp (endopodite) and three endites (Fig. 7g). Palp consisting of two articulated podomeres: first

11 podomere (first endopodite) with five distal setae; second podomere (second endopodite) very small, with two distal setae (Fig. 7g). Endites: dorsal one with five setae (Fig. 7h); middle one with four setae (Fig. 7i); ventral one with five setae (Fig. 7j). Fifth limb (Fig. 8a). Four articulated podomeres. First podomere with one setulous and one stout posterolateral setae, one long antero-lateral seta and two antero-distal setae. Second podomere with one short antero-distal seta. Third podomere bare. Fourth podomere with one distal claw. Sixth limb (Fig. 8b). Four articulated podomeres. First podomere with two setulous setae on anterior middle margin, one stout postero-lateral seta, and one antero-distal seta. Second podomere with one antero-distal seta. Third podomere bare. Fourth podomere with one distal claw. 
2 Second podomere with one setulous antero-distal seta. Third podomere bare. Fourth podomere with one long distal claw

3 with small spines on distal area.

Head capsule (Fig. 8e). Sub-circular in lateral view. One paired rake-shaped structure in atrium space.

Copulatory process very short, bending dorsally (cp). Distal process (dp), lamelliform bending ventrally with flattened

9 seta originating distally. Furca with two setulous setae.

\section{Adult female}

\section{Distribution}

Only recorded from the type locality. 
3 From holotype (UMUT RA32930), 1792 bp of the 18S rRNA gene sequence of Xylocythere sarrazinae sp. nov. was obtained and is available in the DNA Data Bank of Japan/European Molecular Biology Laboratory/NCBI databases under the accession number LC380020.

\section{Etymology}

The new species is named in honor of Dr. Jozée Sarrazin (Ifremer: Institut Français de Recherche pour l'Exploitation de la Mer) for her longtime contribution to deep-sea research and particularly, to vent ecology.

\section{Molecular phylogenetic analysis}

The alignment dataset of 45 sequences of Cytheroidea and two out-groups contained 1452 bp, including 488 variable

sites. jModelTest identified GTR $+\mathrm{I}+\mathrm{G}$ (proportion of invariable sites $=0.45$, gamma shape $=0.50$ ) as the best-fit model under AIC (Akaike, 1974). The molecular phylogenetic analysis performed in this study based on 18S rDNA

16 Cytherurinae join the same clade as Paradoxostomatidae, moderately supported by bootstrap value (79) and

17 Bayesian posterior probability (1.00). (Fig. 10). Although we newly include Cytheroisinae sp. as representatives of subfamily Cytheroisinae (family Paradoxostomatidae), general topology was already demonstrated by previous 


\section{$4 \quad$ Discussion}

5 Xylocythere sarrazinae sp. nov. is easily distinguished from all described species of Xylocythere except for $X$. pointillissima Maddocks and Steineck, 1987. The surface ornamentation of Xylocythere sarrazinae sp. nov. is weak and smooth, in contrast with that of X. trunerae Maddocks and Steineck, 1987, X. rimosa Maddocks and Steineck, 1987, X. tridentis Maddocks and Steineck, 1987, X. vanharteni Maddocks, 2005, X. producta (Colalongo and Pasini, 1980), and X. carpathica Szczechura, 1995, which all show distinctly reticulated surface ornamentation on their carapaces. Other small differences also exist between Xylocythere sarrazinae sp. nov. and the seven other species cited above, as described in the following sentences. (1) The morphology of the male copulatory organ differs between X. trunerae and X. sarrazinae sp. nov. in that: the outline of the basal capsule is sub-circular in the former species, while it is sub-square in the latter; the upper ramus is conical in the former species and spatulate in the latter; and the tip of the distal lobe is tapered distally in the former species, while it is flattened in the latter. (2) Xylocythere rimosa differs from X. sarrazinae sp. nov. because it has a fairly large carapace that is more coarsely reticulated on its exterior surface. (3) Xylocythere tridentis has three large, wedge-shaped denticules located on the anterior margin of the carapace, while X. sarrazinae sp. nov. has only two denticules there that are much smaller. (4) Xylocythere vanharteni has a large, broad, sinuously curved upper ramus on the male copulatory organ, while the shape of upper ramus is spatulate in X. sarrazinae sp. nov. $(5,6)$ The two fossil species, Xylocythere producta and X. carpathica, have much more elongated, wedge-shaped carapaces in lateral view 
compared to that of X. sarrazinae sp. nov. (7) Finally, Xylocythere sarrazinae sp. nov. has a similar morphology to that of

2 X. pointillissima Maddocks and Steineck, 1987, which was described from an experimental wood-fall located off Sainte

3 Croix (Virgin Islands, USA). However, Xylocythere sarrazinae sp. nov. and X. pointillissima can be distinguished based on the following characters: the outline of the basal capsule is sub-square in the former species versus sub-circular in the latter; the upper ramus is spatulate in X. sarrazinae sp. nov. versus conical in X. pointillissima; the tip of the distal lobe of the male copulatory organ is flattened in the former species versus rounded in the latter; and the number of setae on the maxillulal branchial plate is higher in former species than that in the latter (15 versus 12 , respectively). In addition, the overall size of $X$. sarrazinae sp. nov. exceeds that recorded for X. pointillissima at all three locations (Maddocks and Steineck, 1987). Their spatial distributions also differ, as the former species was found in the northeast Pacific at $2196 \mathrm{~m}$ depth, while the latter was found in the western Atlantic at $4000 \mathrm{~m}$ depth. In addition to Xylocythere sarrazinae sp. nov., we found another species of ostracods in the samples, which was Euphilomedes climax Kornicker, 1991 (Myodocopa: Philomedidae). The type locality of E. climax is the Upper

Magic Mountain Vent located at $49^{\circ} 46^{\prime} \mathrm{N}, 130^{\circ} 116^{\prime} \mathrm{W}$ on the Explorer Ridge, northeast Pacific at a depth of $1700 \mathrm{~m}$.

Euphilomedes climax was also previously found on the Juan de Fuca Ridge, at the Long Time Observatory Vent,

Endeavour segment (2250 m) and at the Hammond's Hell Vent, Axial Seamount (1570 m) (Kornicker, 1991), but it was reported from the Grotto edifice for the first time in the present study.

The subfamily Eucytherurinae that includes the genus Xylocythere is characterized by the presence of pore clusters on the carapace (Maddocks and Steineck, 1987). These pore clusters were initially defined by Maddocks and Steineck 
by Van Harten (1993, Figs. 2A, C-D, G-I). These authors considered that it could represent an 'exosymbiosis'. They also proposed that the pore clusters may contribute to the absorption of oxygen. In our new species $X$. sarrazinae sp. nov., multiple spherical structures were observed into the internal openings of the pore clusters, but only in one specimen (Fig. $6 \mathrm{~g}$ ). The shape and size (approximately $1.5 \mu \mathrm{m}$ in diameter) of these structures were similar to those of the chemosynthetic bacteria observed to be symbionts in other invertebrates (Cavanaugh et al. 1981; Cavanaugh 1983; Van Dover et al. 2002). Additional samples would be required to verify the potential links between X. sarrazinae sp. nov. and such bacteria. Finally, our phylogenetic analysis based on 18S rDNA sequences showed that Xylocythere sarrazinae sp. nov. (Eucytherurinae) is the most basal species of cytherurids, with strong nodal support for this conclusion (bootstrap value $=$ 100; Bayesian posterior probability $=1.00$ ). This result supports the taxonomic arrangement of there being three subfamilies within the family Cytheruridae (Cytherurinae, Cytheropterinae and Eucytherurinae), as proposed by

12 Maddocks and Steineck (1987) and Mazzini and Gliozzi (2000), rather than two (Cytherurinae and

13 Cytheropterinae), as proposed by Whatley and Boomer (2000). The fossil record of Cytheruridae extends back to the early Mesozoic or possibly the latest Permian. Species of the extant genera Eucytherura (Eucytherurinae) and Cytheropteron (Cytheropterinae) are known from the Triassic and Jurassic, respectively (Whatley and Boomer 2000). The basal position of Xylocythere sarrazinae sp. nov. in the molecular phylogenetic analysis performed in this study supports the hypothesized ancient origin of Eucytherurinae. Although our phylogenetic analysis is preliminary in nature because it was based on a single gene (18S) and limited taxon sampling, we used all of the available data that could possibly reconstruct the subfamily level phylogeny within Cytheroidea at the present time. The accumulation of 
more genetic data than just $18 \mathrm{~S}$ sequences and increased taxon sampling will allow the phylogenetic relationships within

4 Acknowledgements

5 The authors thank the captain and crew of the $R / V$ Thomas $G$. Thompson and the staff of Ocean Networks Canada and

6 ROV's Jason pilots during the "Ocean Networks Canada Expedition 2015: Wiring the Abyss" cruise. We thank also Kim

7 Juniper and the government of Canada in obtaining of works permit to study in Canadian waters (XR281, 2015). We are also grateful to Thomas Day for his assistance in sample sorting and Akira Tsukagoshi for providing the research

9 facilities for taxonomy and molecular work. The work described in this article was partially supported by the grants from the Japan Society for the Promotion of Science for Young Scientists (No. 263700) (to HT), the Research Grants Council of the Hong Kong Special Administrative Region, China (project codes: HKU 17306014, HKU 17311316) (to MY). This research was part of Yann Lelièvre PhD thesis supervised by Legendre, P. (Université de Montréal) as well as Mariolaine research grant to Pierre Legendre, Ifremer internal funds and a fellowship from the "Laboratoire d'Excellence"

17 Funding: This study was funded by the grants from the Japan Society for the Promotion of Science for Young Scientists 
4 Conflict of Interest: The authors declare that they have no conflict of interest.

Ethical approval: All applicable international, national, and/or institutional guidelines for the care and use of animals were followed by the authors.

9 Sampling and field studies: All necessary permits for sampling and observational field studies have been obtained by

10 the authors from the competent authorities and are mentioned in the acknowledgements.

\section{References}

13 Akaike H (1974) A new look at the statistical model identification. IEEE Trans on Autom Control 19:716-723

14 Altschul SF, Gish W, Miller W, Myers EW, Lipman DJ (1990) Basic local alignment search tool. J Mol Biol 215:403-

16 Altschul SF, Madden TL, Schäffer AA, Zhang J, Zhang Z, Miller W, Lipman DJ (1997) Gapped BLAST and PSI-

17 BLAST: a new generation of protein database search programs. Nucleic Acids Res 25:3389-3402

18 Bergue CT, Coimbra JC (2008) Late Pleistocene and Holocene bathyal ostracodes from the Santos Basin, southeastern 
1 Castresana J (2000) Selection of conserved blocks from multiple alignments for their use in phylogenetic analysis. Mol

$2 \quad$ Biol and Evol 17:540-552

3 Cavanaugh CM, Gardiner SL, Jones ML, Jannasch HW, Waterbury JB (1981) Prokaryotic cells in the hydrothermal vent

4 tube worm Riftia pachyptila Jones: Possible chemoautotrophic symbionts. Science 213:340-342

5 Cavanaugh CM (1983) Symbiotic chemoautotrophic bacteria in marine invertebrates from sulphide-rich habitats. Nature

$6 \quad 302: 58-61$

7 Colalongo ML, Pasini G (1980) La ostracofauna plio-pleistocenica della sezione Vrica in Calabria (con considerazioni

sul limite Neogene/Quaternario). B Soc Paleontol Ital 19:44-126

9 Corrège T (1993) The relationship between water masses and benthic ostracod assemblages in the western Coral Sea,

10 Southwest Pacific. Palaeogeogr Palaeoclimatol, Palaeoecol 105:245-266

11 Dall'Antonia B (2003) Miocene ostracods from the Tremiti Islands and Hyblean Plateau: biostratigraphy and description

12 of new and poorly known species. Geobis 36:27-54

13 Darriba D, Taboada GL, Doallo R, Posada D (2012) jModelTest 2: more models, new heuristics and parallel computing.

14 Nat Methods 9:772.

15 Degen R, Riavitz L, Gollner S, Vanreusel A, Plum C, Bright M (2012) Community study of tubeworm-associated

16 epizooic meiobenthos from deep-sea cold seeps and hot vents. Mar Ecol Prog Ser 468:135-148

17 Felsenstein J (1985) Confidence limits on phylogenies: an approach using the bootstrap. Evolution 39:783-791

18 Guindon S, Gascuel O (2003) A simple, fast and accurate algorithm to estimate large phylogenies by maximum 
1 Guindon S, Dufayard JF, Lefort V, Anisimova M, Hordijk W, Gascuel O (2010) New algorithms and methods to estimate

2 maximum-likelihood phylogenies: assessing the performance of PhyML 3.0. Syst Biol 59:307-321

3 Karanovic I, Brandão SN (2015) Biogeography of deep-sea wood fall, cold seep and hydrothermal vent Ostracoda

4 (Crustacea), with the description of a new family and a taxonomic key to living Cytheroidea. Deep Sea Res Part II: Top

$5 \quad$ Stud Oceanogr 111:76-94

6 Katoh K, Misawa K, Kuma KI, Miyata T (2002) MAFFT: a novel method for rapid multiple sequence alignment based

7 on fast Fourier transform. Nucleic Acids Res 30:3059-3066

8 Katoh K, Kuma KI, Toh H, Miyata T (2005) MAFFT version 5: improvement in accuracy of multiple sequence

9 alignment. Nucleic Acids Res 33:511-518

10 Katoh K, Standley DM (2013) MAFFT multiple sequence alignment software version 7: improvements in performance

11 and usability. Mol Biol Evol 30:772-780

12 Kelley DS, Carbotte SM, Caress DW, Clague DA, Delaney JR, Gill JB, Hadaway H, Holden JF, Hooft EEE, Kellogg JP,

13 Lilley MD, Stoermer M, Toomey D, Weekly R, Wilcock WSD (2012) Endeavour Segment of the Juan de Fuca Ridge:

14 One of the most remarkable places on Earth. Oceanography 25:44-61

15 Kiel S, Goedert JL (2006) A wood-fall association from Late Eocene deep-water sediments of Washington State, USA.

16 Palaios 21:548-556

17 Kornicker LS (1991) Myodocopid Ostracoda of hydrothermal vents in the eastern Pacific Ocean. Smithson Contr Zool

18 516:1-46 
1 Kornicker LS, Harrison-Nelson E (2005) Two new species of Ostracoda from hydrothermal vents of Riftia pachyptila

2 aggregations on the East Pacific Rise (Halocypridina; Cladocopina). Zootaxa 1071:19-38

3 Lelièvre Y, Sarrazin J, Marticorena J, Schaal G, Day T, Legendre P, Hourdez S, Matabos M (2018) Biodiversity and

4 trophic ecology of hydrothermal vent fauna associated with tubeworm assemblages on the Juan de Fuca Ridge.

5 Biogeosciences 15:2629-2647

6 Machian-Castillo ML, Gío-Argáez FR, Escobar-Briones E (2014) Foraminíferos y ostrácodos recientes de la zona batial

7 y abisal del sur del Golfo de México. In: Low Pfeng A, Peters Recagno EM (eds) La frontera final: el océano profundo.

8 INECC, Mexico, pp. 153-173.

9 Maddocks RF (2005) Three new species of podocopid Ostracoda from hydrothermal vent fields at $9^{\circ} 50^{\prime} \mathrm{N}$ on the East

10 Pacific Rise. Micropaleontology 51:345-372

11 Maddocks RF, Steineck PL (1987) Ostracoda from experimental wood-island habitats in the deep sea. Micropaleontology

$12 \quad 33: 318-355$

13 Mazzini I, Gliozzi E (2000) Occurrence of fossil and Recent Microceratina Swanson 1980 (Ostracoda, Eucytherurinae)

14 in the Mediterranean. Micropaleontology 46:143-152

15 Moon-van der Staay SY, van der Staay GWM, Guillou L, Vaulot D, Claustre H, Medlin LK (2000) Abundance and

16 diversity of prymnesiophytes in the picoplankton community from the equatorial Pacific Ocean inferred from 18S rDNA

sequences. Limnol Oceanogr 45:98-109

18 Nylander JAA (2004) MrModeltest v2. Program distributed by the author. Evolutionary Biology Centre, Uppsala

19 University 
1 Olempska E, Belka Z (2010) Hydrothermal vent myodocopid ostracods from the Eifelian (Middle Devonian) of southern

2 Morocco. Geobis 43:519-529

3 Rambaut A, Suchard MA, Xie MA, Drummond AJ (2014) Tracer v1.6. Available from: http://beast.bio.ed.ac.uk/Tracer

$4 \quad$ [Accessed on 12 Feb 2018]

5 Ronquist F, Huelsenbeck JP (2003) MrBayes 3: Bayesian phylogenetic inference under mixed models. Bioinformatics

$6 \quad 19: 1572-1574$

7 Sarrazin J, Juniper K (1999) Biological characteristics of a hydrothermal edifice mosaic community. Mar Ecol Prog Ser

$8 \quad 185: 1-19$

9 Sarrazin J, Robigou V, Juniper K, Delaney JR (1997) Biological and geological dynamics over four years on a high-

10 temperature sulfide structure at the Juan de Fuca Ridge hydrothermal observatory. Mar Ecol Prog Ser 153:5-24

11 Steineck PL, Maddocks RF, Coles G, Whatley RC (1990) Xylophile Ostracoda in the deep sea. In: Whatley R, Maybury

$12 \mathrm{C}$ (eds) Ostracoda and Global Events. British Micropaleontological Society Publication Series, Chapman and Hall,

13 London, pp. 307-319

14 Szczechura J (1995) The ostracode genus Xylocythere Maddocks and Steineck, 1987, from the Middle Miocene of the

15 Fore-Carpathian Depression, southern Poland (Central Paratethys), and its biogeographic significance. Acta Geol Pol

$16 \quad 45: 27-40$

17 Szczechura J (2000) Age and evolution of depositional environments of the supra-evaporitic deposits in the northern,

18 marginal part of the Carpathian Foredeep: micropalaeontologica1 evidence. Geol Quart 44:81-100 
1 Tanaka H, Ohtsuka S (2016) Historical biogeography of the genus Polycopissa (Ostracoda: Myodocopa: Cladocopina),

2 with the description and DNA barcode of the second Indo-Pacific species

3 from the Seto Inland Sea. Mar Biodiv 46:625-640

4 Tanaka H, Yasuhara M (2016) A new deep-sea hydrothermal vent species of Ostracoda (Crustacea) from the Western

5 Pacific: Implications for adaptation, endemism, and dispersal of ostracodes in chemosynthetic systems. Zool Sci 33:555-

$6 \quad 565$

7 Van Dover CL (2002) Community structure of mussel beds at deep-sea hydrothermal vents. Mar Ecol Prog Ser 230:137-

$8 \quad 158$

9 van Harten D (1992) Hydrothermal vent Ostracoda and faunal association in the deep sea. Deep Sea Research Part A 39:

$10 \quad 1067-1070$

11 van Harten D (1993) Deep sea hydrothermal vent eucytherurine Ostracoda: the enigma of the pore clusters and the

12 paradox of the hinge. In: McKenzie KG, Jones PJ (eds) Ostracoda in the Earth and Life Sciences. Balkema, Rotterdam,

13 pp. $571-580$

14 Whatley R, Boomer I (2000) Systematic review and evolution of the early Cytheruridae (Ostracoda). J Micropalaeont

$15 \quad 19: 139-151$

16 Xu G, Jackson, DR Bemis KG, Rona PA (2014) Time-series measurement of hydrothermal heat flux at the Grotto

17 mound, Endeavour Segment, Juan de Fuca Ridge. Ear Planet Sci Let 404:220-231

18 Yamaguchi S (2003) Morphological evolution of cytherocopine ostracods inferred from 18S ribosomal DNA sequences. J

19 Crust Biol 23:131-153 
Yasuhara M, Okahashi H, Cronin TM (2009) Taxonomy of Quaternary deep-sea ostracods from the western North

Zeppilli D, Danovaro R (2009) Meiofaunal diversity and assemblage structure in a shallow-water hydrothermal vent in

\section{Figure legends}

Fig. 1 Global distribution and fossil occurrences of Xylocythere species. Species list and references are shown in Table 1.

9 Numbers correspond with localities: 1, 190 miles southeast of Woods Hole, depth 3506 m; 2, Tongue of the Ocean,

10 Bahama Islands, depth 2066 m; 3, off north coast of St. Croix, Virgin Islands, depth 4000 m; 4, Panama Basin, depth

113900 m; 5, this study, Juan de Fuca Ridge, depth 2196 m, details are shown in Fig. 2; 6, Tica and Riftia hydrothermal

12 vent fields at $9^{\circ} 50^{\prime} \mathrm{N}$ on the East Pacific Rise, depth $2500 \mathrm{~m}$; 7, Tremiti Islands, fossil; 8, Calabria, fossil; 9, Hyblean

13 Plateau, fossil; 10, Jamnica borehole, southern Poland, fossil; 11, Goban Spur, Northeast Atlantic Ocean, Deep Sea

14 Drilling Site S49A, fossil; 12, Queensland Plateau, southwest Pacific, Deep Sea Drilling Site 209, fossil; 13, northwest

15 Gulf of Mexico, depth 1500 m, fossil; 14, Central equatorial Pacific, Deep Sea Drilling Site 575A, fossil; 15, western

16 Coral Sea, depth 2023 m, fossil; 16, western Coral Sea, depth 2230 m, fossil; 17, Mason County, western Washington

17 State, United States, fossil; 18, Santos Basin, Brazil, fossil; 20, Carolina Slope, western North Atlantic, Ocean Drilling

18 Program Site 1055, depth 1795 m, fossil; 20, southern Gulf of Mexico, depth 2929 m, fossil. 
1 Fig. 2 Sampling locality. a location of the Juan de Fuca Ridge, northeast Pacific and the seven segments. A rectangular

2 indicating the Main Endeavour Field. b Bathymetric map and the positions of hydrothermal vent edifices of the Main

3 Endeavour Field (Endeavour, Juan de Fuca Ridge). A star indicating the Grotto hydrothermal edifice, the type locality of

$4 \quad$ Xylocythere sarrazinae sp. nov.

$5 \quad$ Fig. 3 Scatter plots of valves of Xylocythere sarrazinae sp. nov. from the type locality. Triangle and circle indicate male

6 and female, respectively.

7 Fig. 4 External view of valves of Xylocythere sarrazinae sp. nov., male, holotype (UMUT RA32930). a internal lateral view of left valve; $\mathbf{b}$ internal lateral view of right valve. Scale bar $100 \mu \mathrm{m}$.

9 Fig. 5 Scanning electron microscope images of valves of Xylocythere sarrazinae sp. nov. a, b male paratype (UMUT

10 RA32931); $\mathbf{c}, \mathbf{d}$ male paratype (UMUT RA32932); e, $\mathbf{f}$ female paratype (UMUT RA32937); $\mathbf{g}$ male paratype (UMUT

11 RA32933); h female paratype (UMUT RA32938): a external lateral view of right valve; $\mathbf{b}$ external lateral view of left valve; $\mathbf{c}$ internal lateral view of right valve; $\mathbf{d}$ internal lateral view of left valve; $\mathbf{e}$ external lateral view of right valve; $\mathbf{f}$ external lateral view of left valve; $\mathbf{g}$ dorsal view of carapace, a posteriorly-directed postero-ventral spine of both valves are broken; $\mathbf{h}$ dorsal view of carapace. Scale bar $100 \mu \mathrm{m}$.

Fig. 6 Scanning electron microscope images of valves of Xylocythere sarrazinae sp. nov., internal lateral view, male paratype (UMUT RA32932). a hingement of left valve; b hingement of right valve; $\mathbf{c}$ posterior element of left valve; $\mathbf{d}$ posterior element of right valve; $\mathbf{e}$ anterior element of left valve; $\mathbf{f}$ anterior element of right valve; $\mathbf{g}$ internal view of pore clusters; $\mathbf{h}$ adductor muscle scars. Scale bars $100 \mu \mathrm{m}(\mathbf{a}, \mathbf{b}), 50 \mu \mathrm{m}(\mathbf{c}-\mathbf{h})$. 
Fig. 7 Xylocythere sarrazinae sp. nov. a, b male holotype (UMUT RA32930); c-f male paratype (UMUT RA32932); g-j male paratype (UMUT RA32934). a antennula; b antenna; $\mathbf{c}$ mandibula; d mandibula, first podomere of endopodite; $\mathbf{e}$ mandibula, coxal endites; f maxillula, branchial plate and refluxed setae; $\mathbf{g}$ maxillula, palp and endites (without setae); $\mathbf{h}$ maxillula, dorsal endite; $\mathbf{i}$ maxillula, middle endite; $\mathbf{j}$ maxillula, ventral endite. Abbreviations and numbers at tips of setae indicate the segments of insertion: $1 e n$ to $4 e n$, first to fourth endopodite; 4 to 6 , fourth to sixth podomere. Scale bars $50 \mu$ m.

6 Fig. 8 Xylocythere sarrazinae sp. nov. a-c male paratype (UMUT RA32932); d, e male paratype (UMUT RA32935). a fifth limb; b sixth limb; c seventh limb; d brush-shaped organ; e head capsule in left lateral view. Scale bars $50 \mu \mathrm{m}$

Fig. 9 Xylocythere sarrazinae sp. nov. a male copulatory organ and posterior body, holotype (UMUT RA32930); b female copulatory organ and posterior body, paratype (UMUT RA32937). Abbreviations: $c p$ copulatory process, $d p$ distal process, lra lower ramiform appendage, ur upper ramus. Scale bars $50 \mu \mathrm{m}$.

11 Fig. 10 a Maximum likelihood (ML) tree based on 18S rDNA sequences using the GTR+I+G model of nucleotide substitution. The number of branches indicate bootstrap value (ML) and posterior probabilities (Bayesian inference).

13 Scale bar indicates substitutions per site. The clade including Xylocythere sarrazinae sp. nov. indicated by gray box. b the cladogram of clade including $X$. sarrazinae sp. nov. extracted from Fig. 9a. Scanning electron microscope image shows left valves in external view: the upper row, X. sarrazinae sp. nov., Cytheropteron sp., Semicytherura sagittiformis 
1 Table 1 Species list of living and fossil Xylocythere. Numbers correspond with locality are indicated in Fig. 1.

2 Abbreviations: E, Eocene; H, Holocene; HV, hydrothermal vent; M, Miocene; Og, Oligocene; Ps, Pleistocene; WF, wood

3 fall.

\begin{tabular}{cccccccccccc}
\hline Late & Late & Early & Middle & Lare & Eearly & Late & & Recent & Recent & \\
& E & Og & M & M & M & Ps & Ps & H & HV & WF & \\
\hline
\end{tabular}

Xylocythere trunerae

Maddocks and Steineck,

1987

X. pointillissima

Maddocks and Steineck,

1987

X. rimosa Maddocks

and Steineck, 1987

X. tridentis Maddocks

and Steineck, 1987

$X$. sarrazinae sp. nov.

X. vanharteni

Maddocks, 2005

X. producta (Colalongo

and Pasini, 1980)

7,9

8

X. carpathica

Szczechura, 1995

10

$X$. sp. 1 from Steineck et

al. (1990)

$X$. sp. 2 from Steineck et

al. (1990)

X. sp. 3 from Steineck et

al. (1990)

$X$. sp. 4 from Steineck et

al. (1990)

$X$. sp. 5 from Steineck et

al. (1990)

\section{Maddocks and \\ Steineck (1987)}

Maddocks and

1, 2, 3 Steineck (1987)

Maddocks and

4

Steineck (1987)

Maddocks and

Steineck (1987)

This study

Van Harten (1992,

1993); Maddocks

(2005)

Colalongo and Pasini

(1980); Dall'Antonia

Szczechura (1995,

2000)

Steineck et al. (1990)

Steineck et al. (1990)

Steineck et al. (1990)

Steineck et al. (1990)

Steineck et al. (1990) 
$X$. sp. 6 from Steineck et

al. (1990)

$X$. sp. 7 from Steineck et

al. (1990)

$X$. sp. from Corrège

(1993)

$X$. sp. from Kiel and

Goedert (2006)

$X$. sp. from Bergue and

Coimbra (2008)

$X$. sp. from Yasuhara et

al. (2009)

$X$. sp. from Machian-

Castillo et al. (2014)
Steineck et al. (1990)

14

Steineck et al. (1990)

15 ,

16

Corrège (1993)

Kiel and Goedert

(2006)

Bergue and Coimbra

(2008)

Yasuhara et al. (2009)

Machian-Castillo et

al. (2014)

2 Table 2 Dimension of valves of Xylocythere sarrazinae sp. nov. from the type locality.

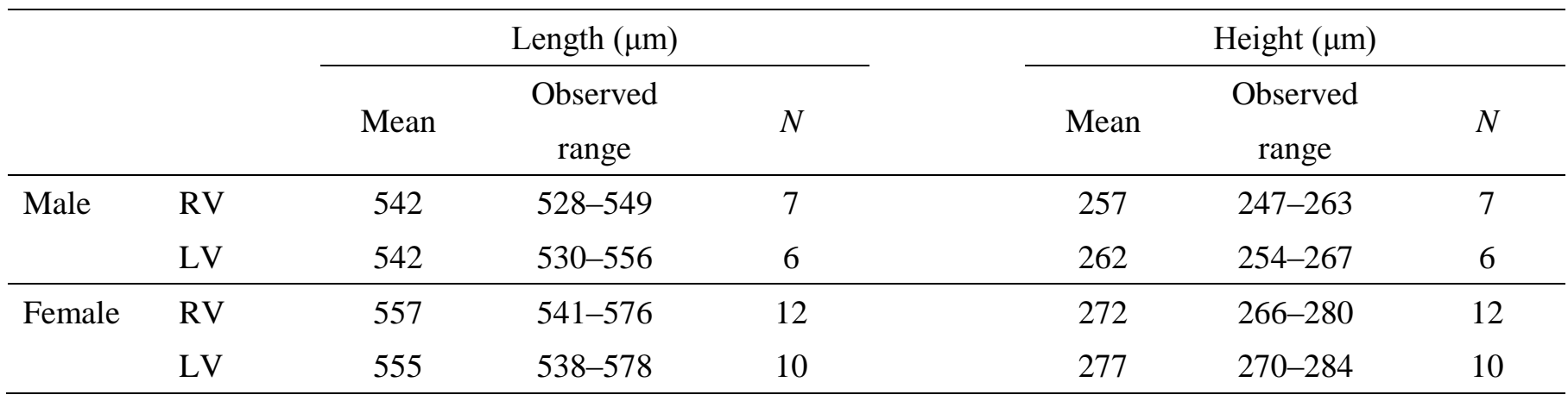




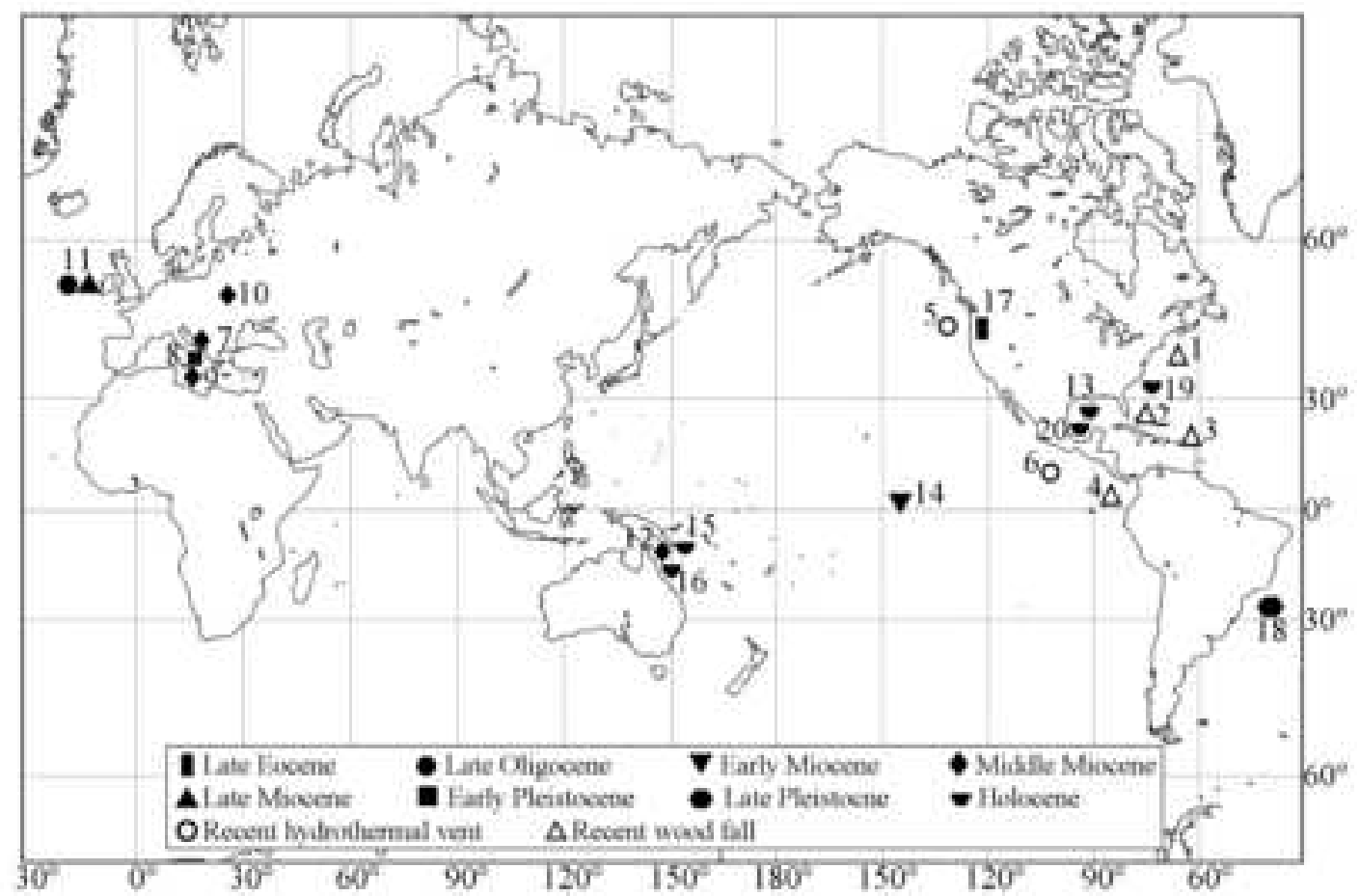

Fig. 1 

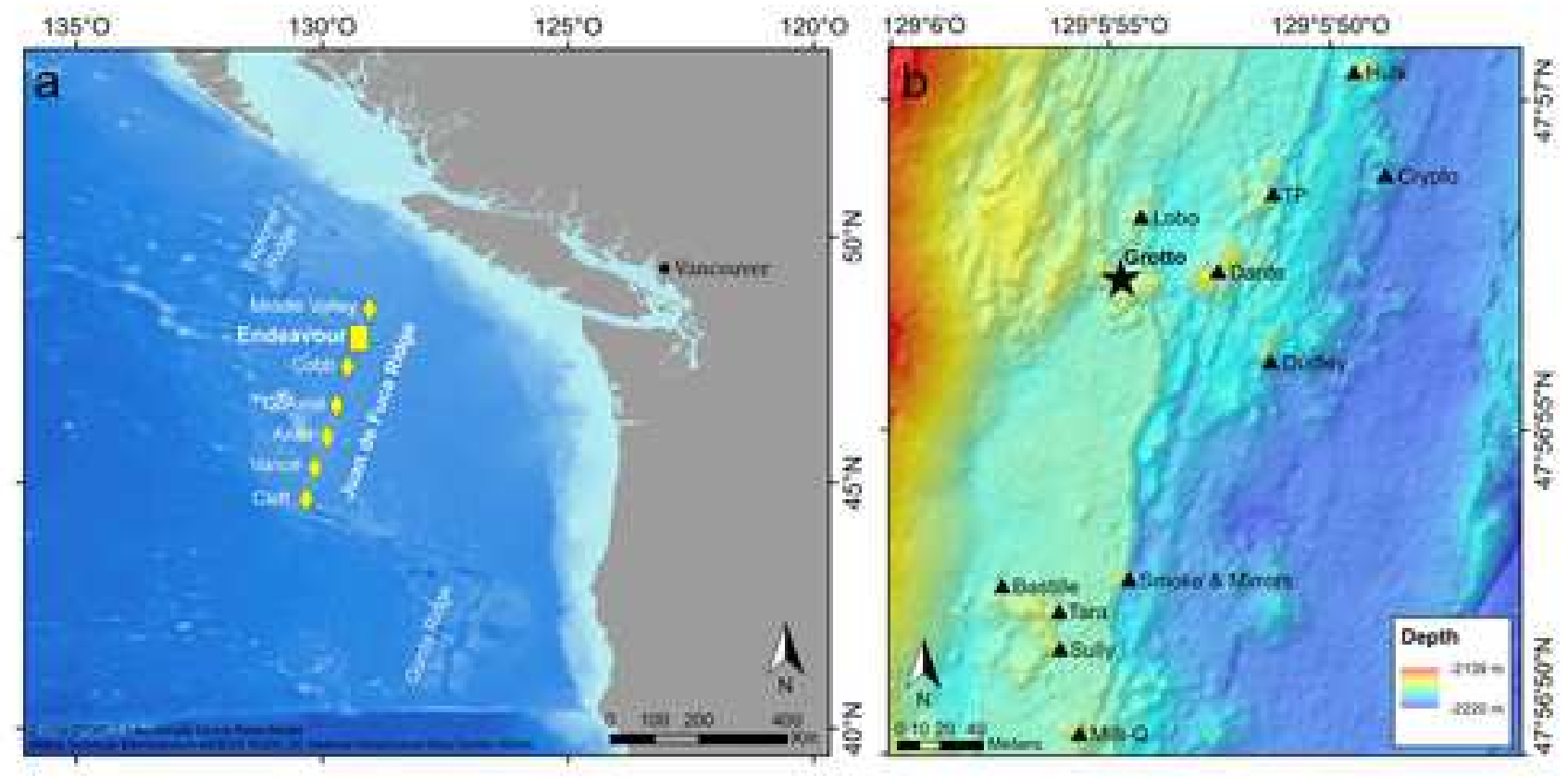

Fig. 2 

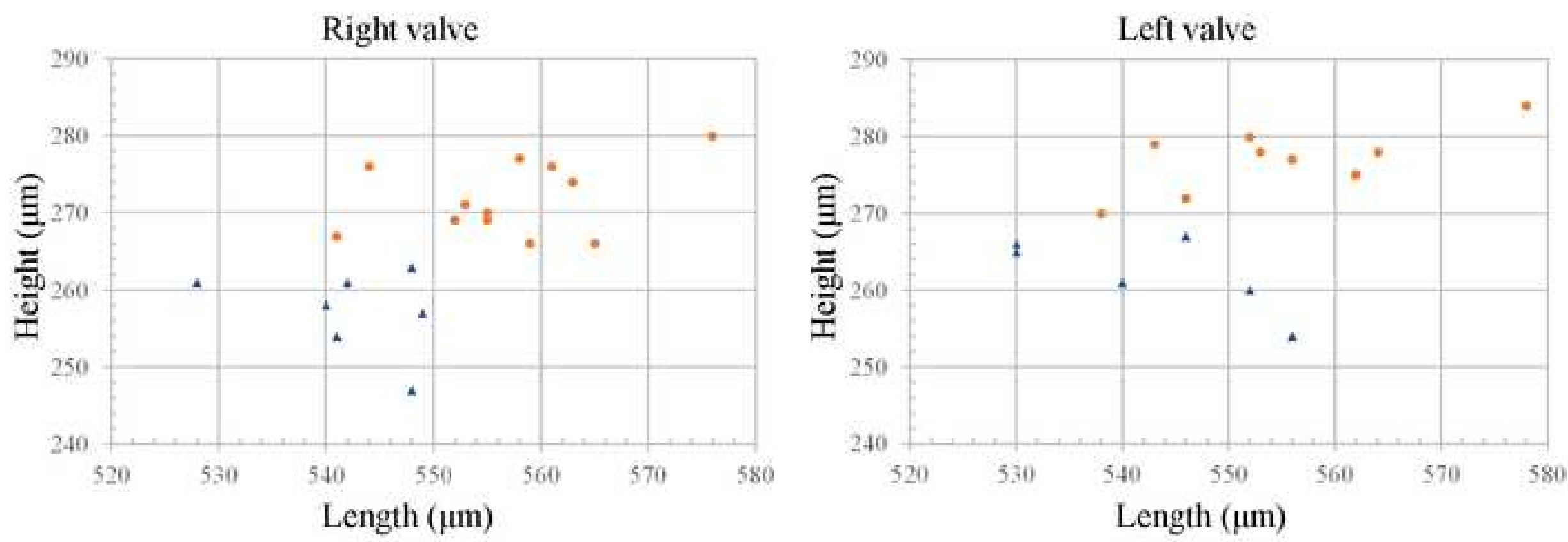

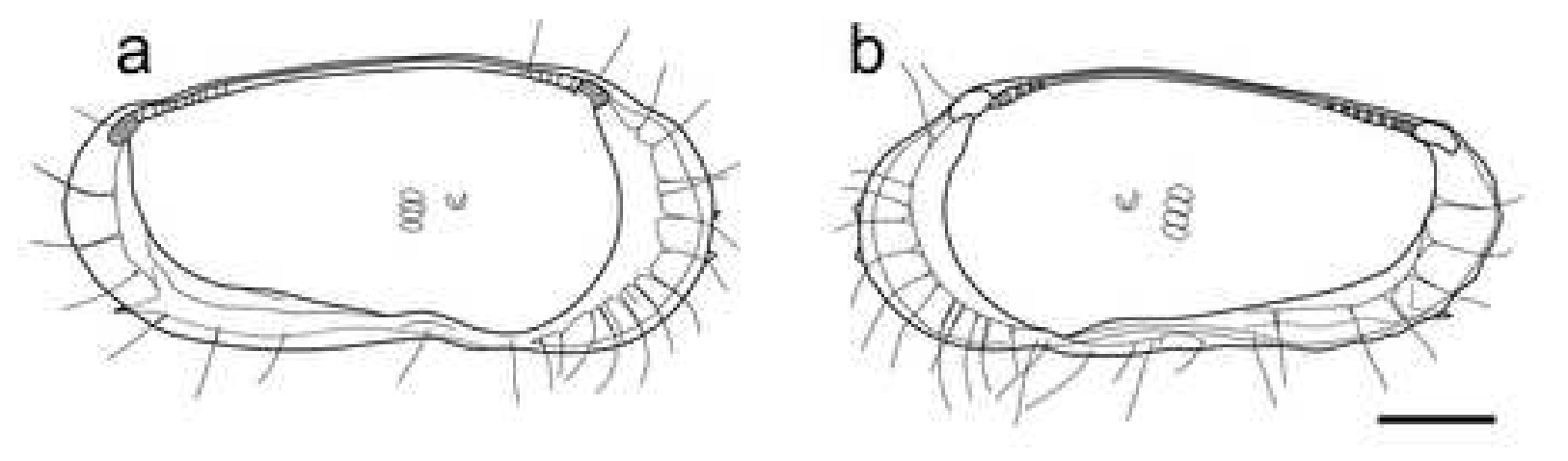

(1)

(1) \\ (1)
}

(3)

\section{.}

(1)
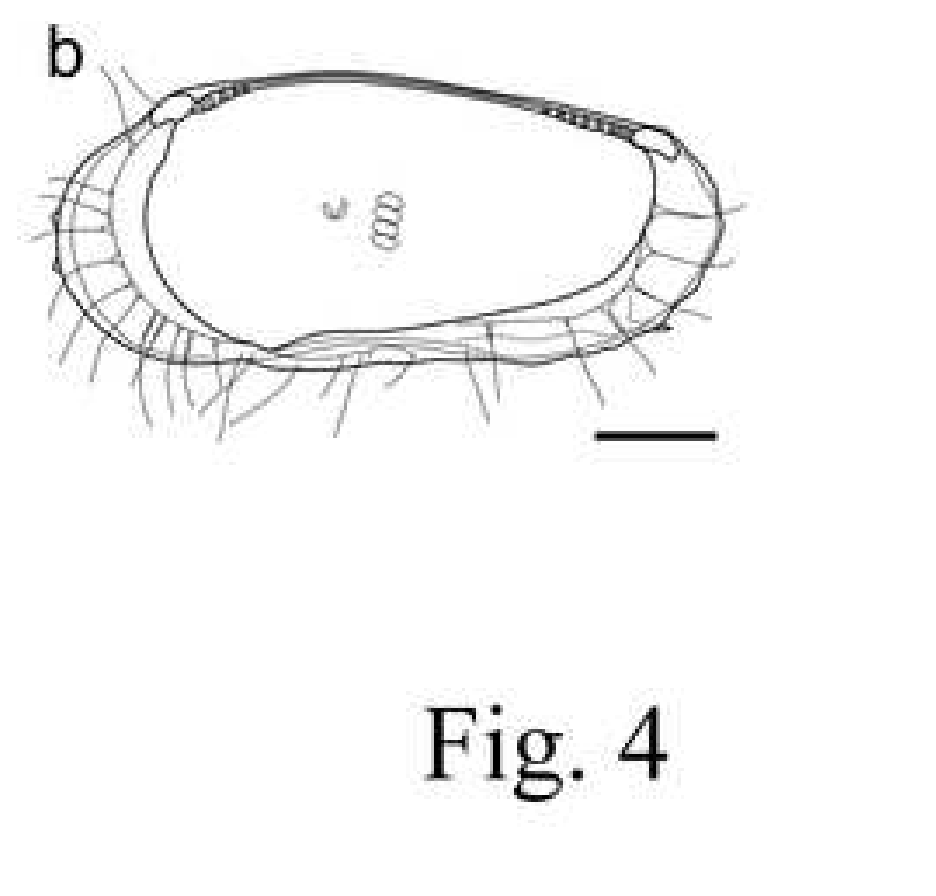

Click here to access/download;Figure;Figure 4.jpg

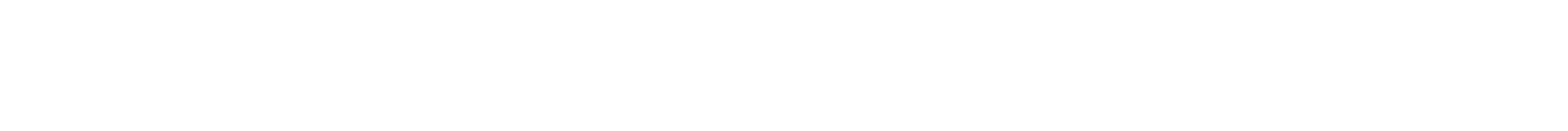

\author{
Fig. 4
}




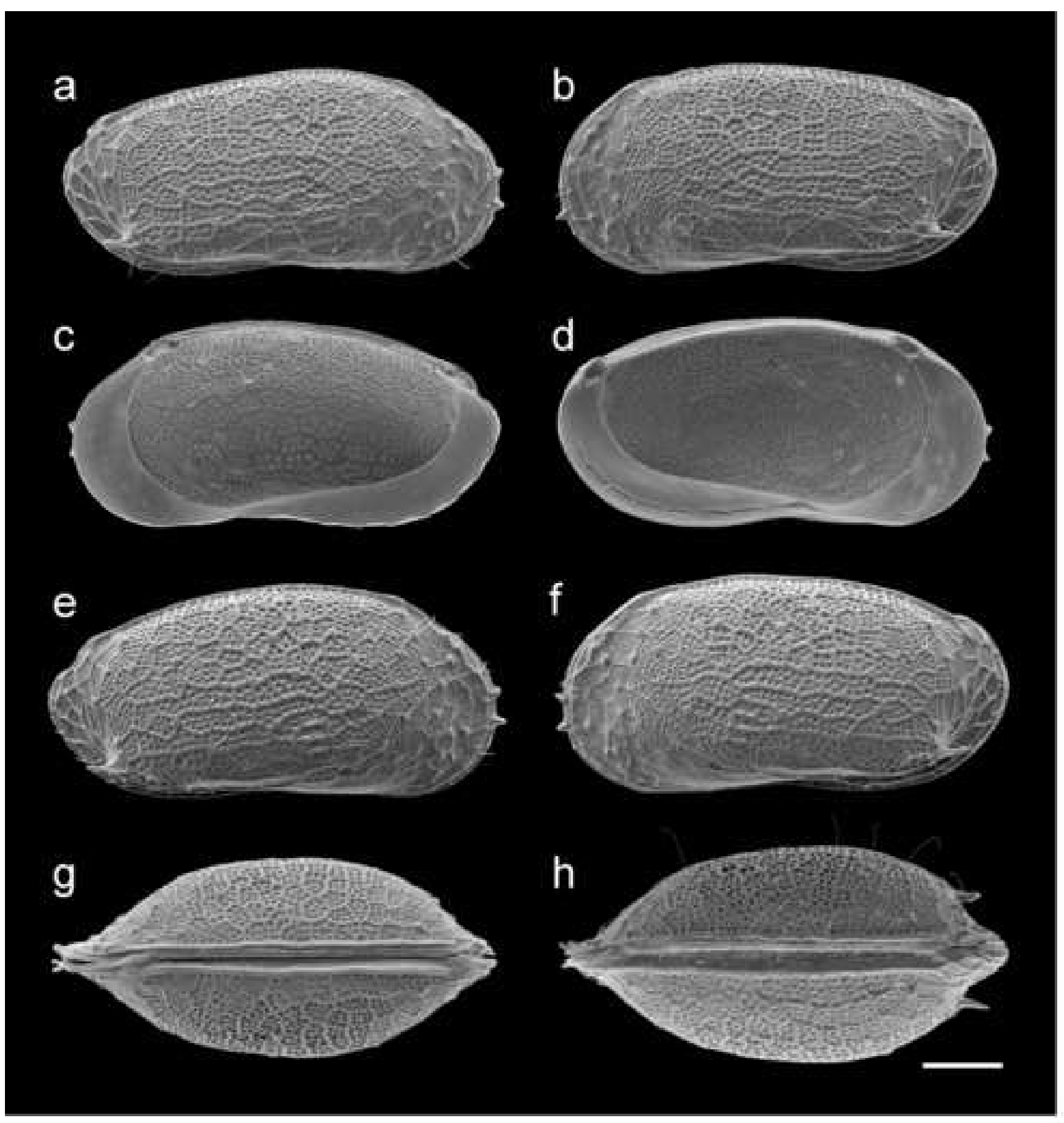

\section{Fig. 5}

.

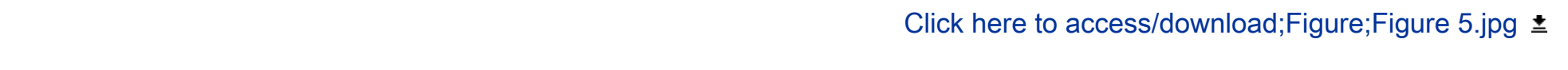




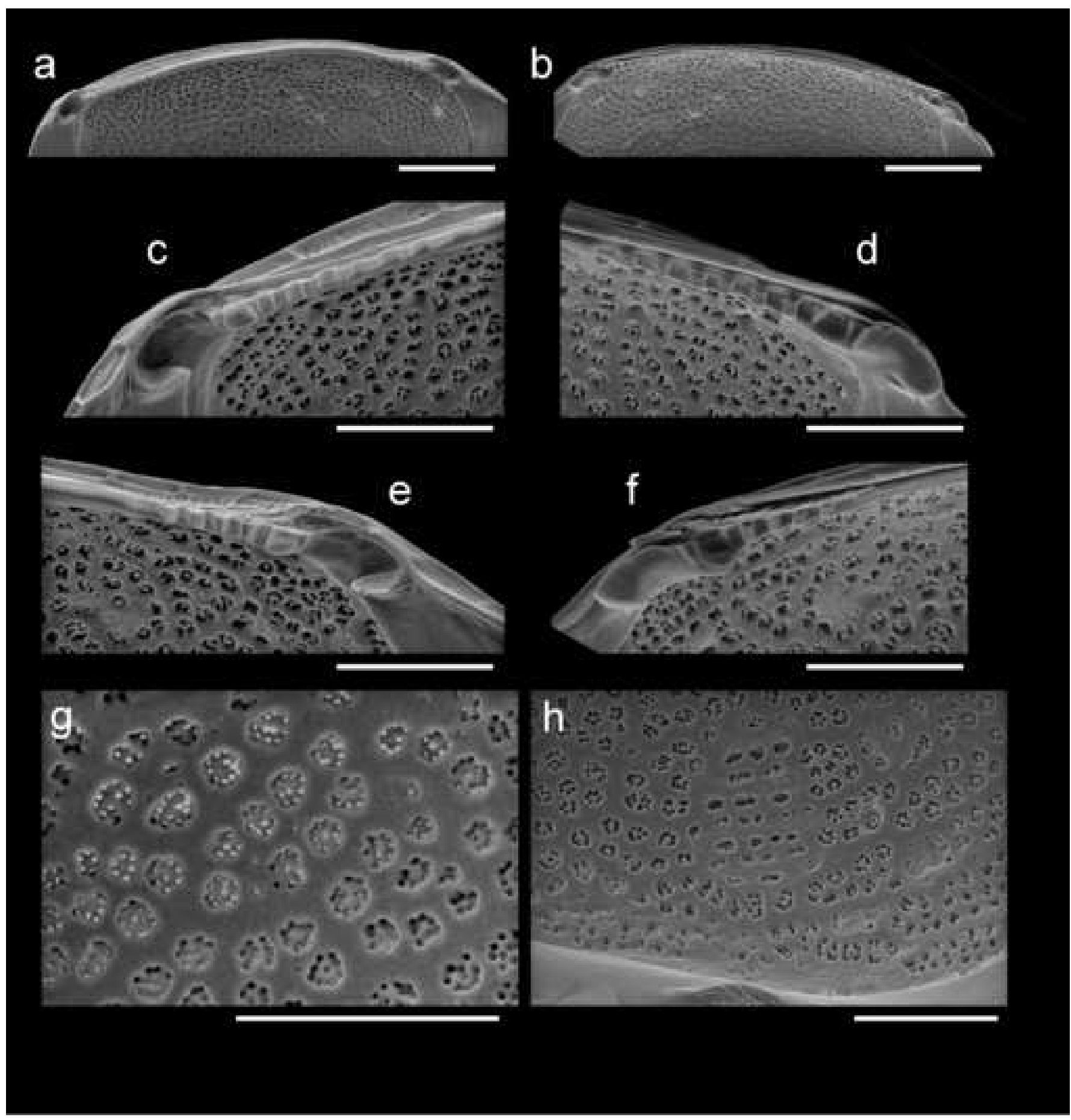

Fig. 6 


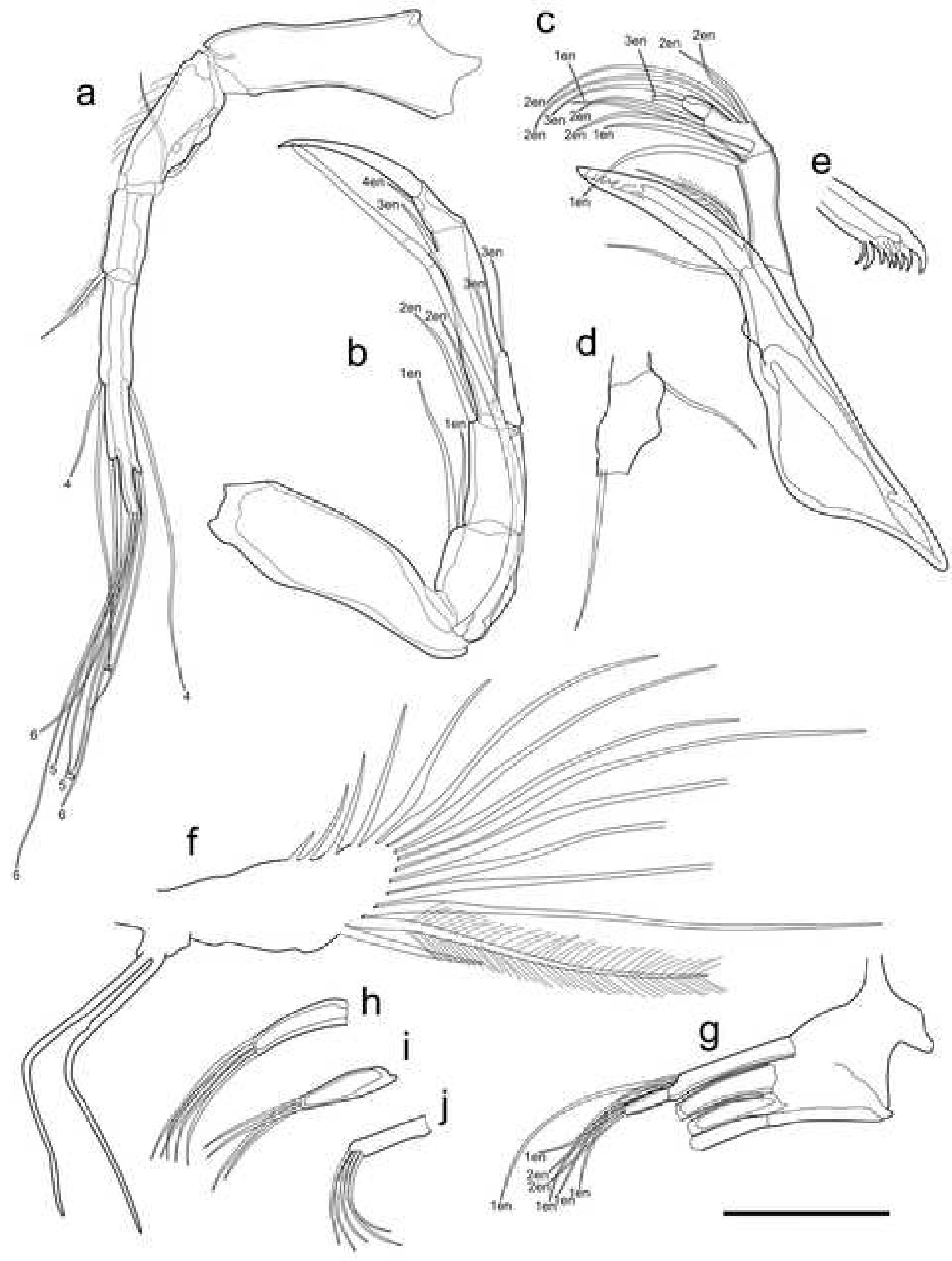

Fig. 7 


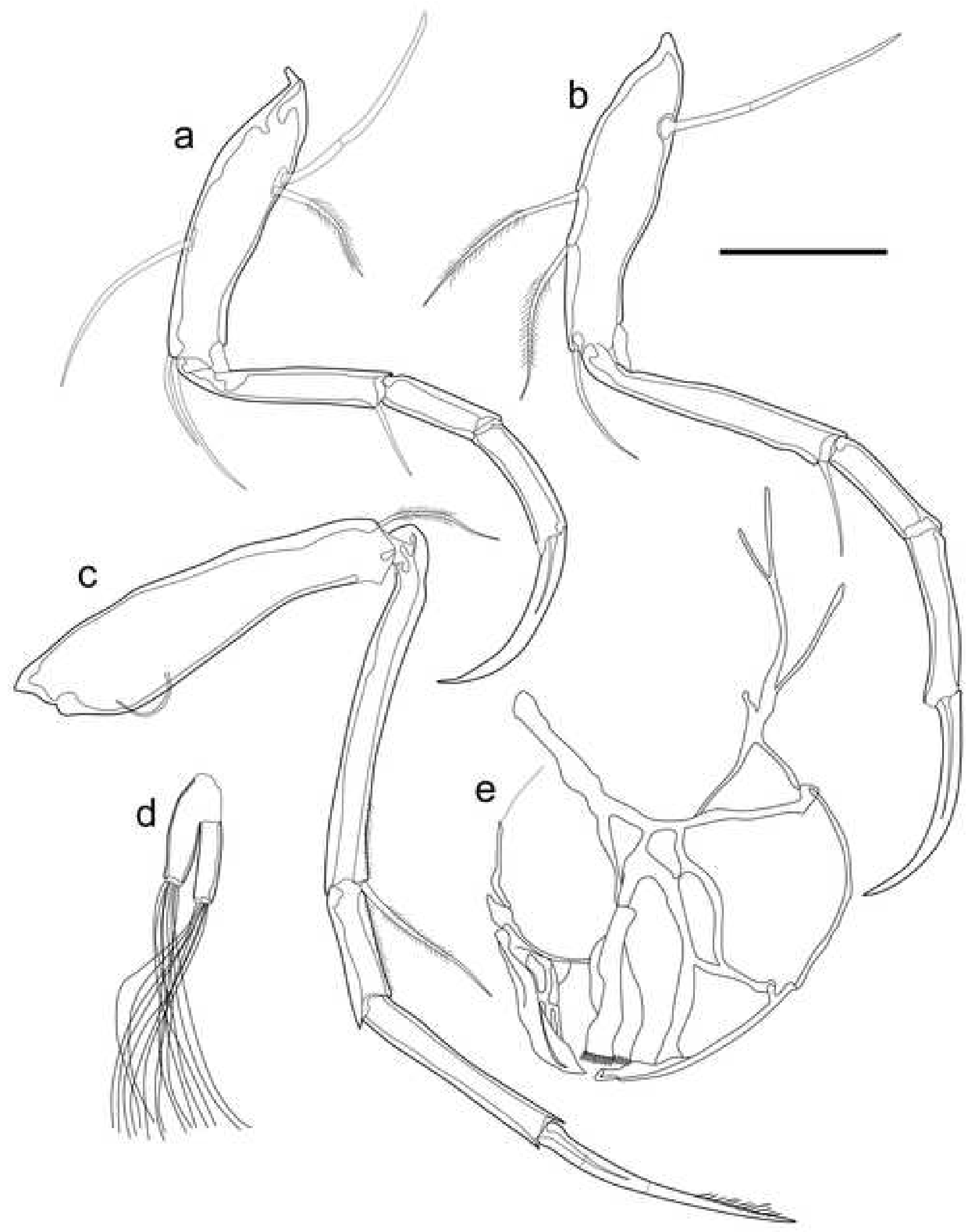

Fig. 8 


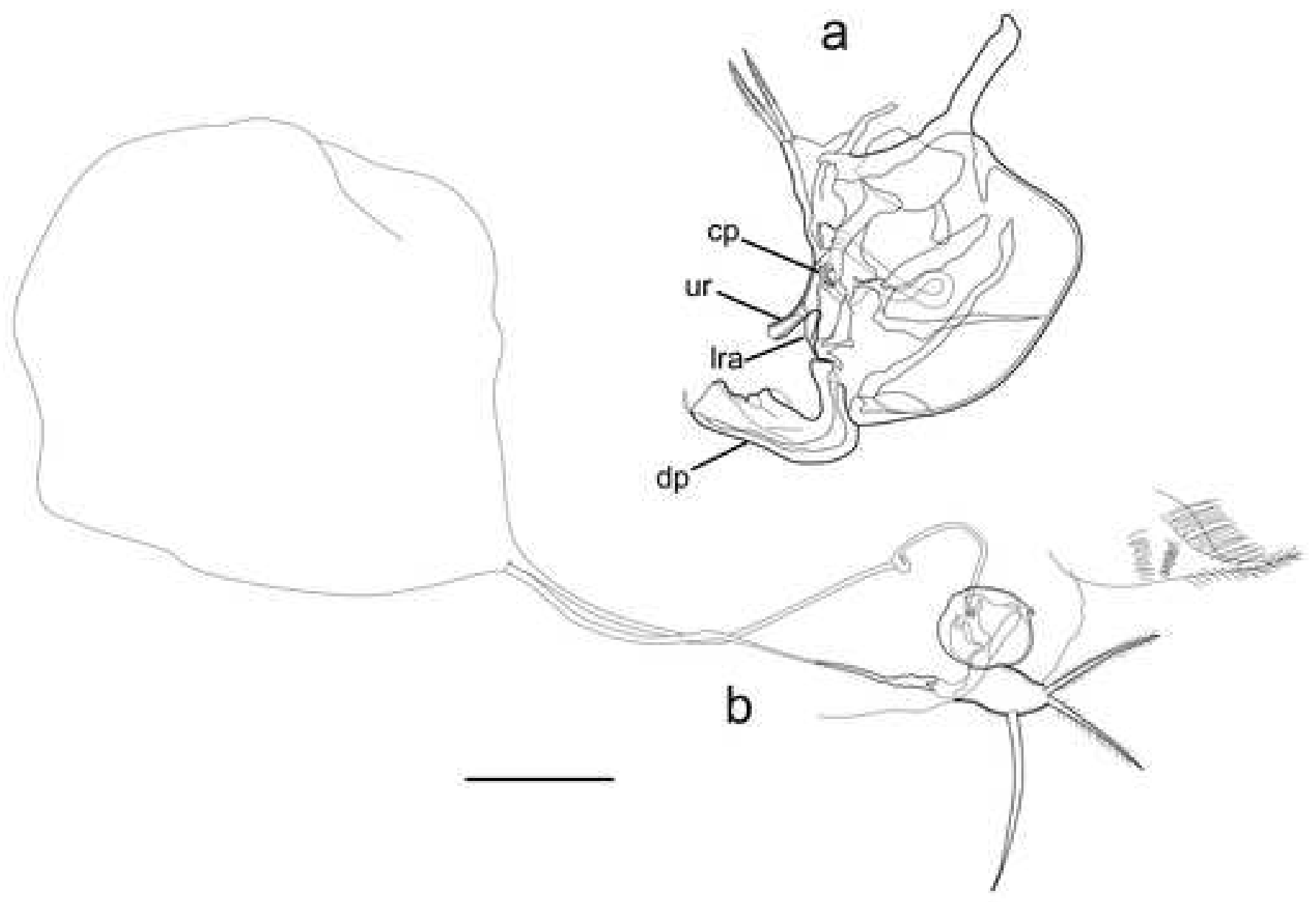

Fig. 9

Figure 9 


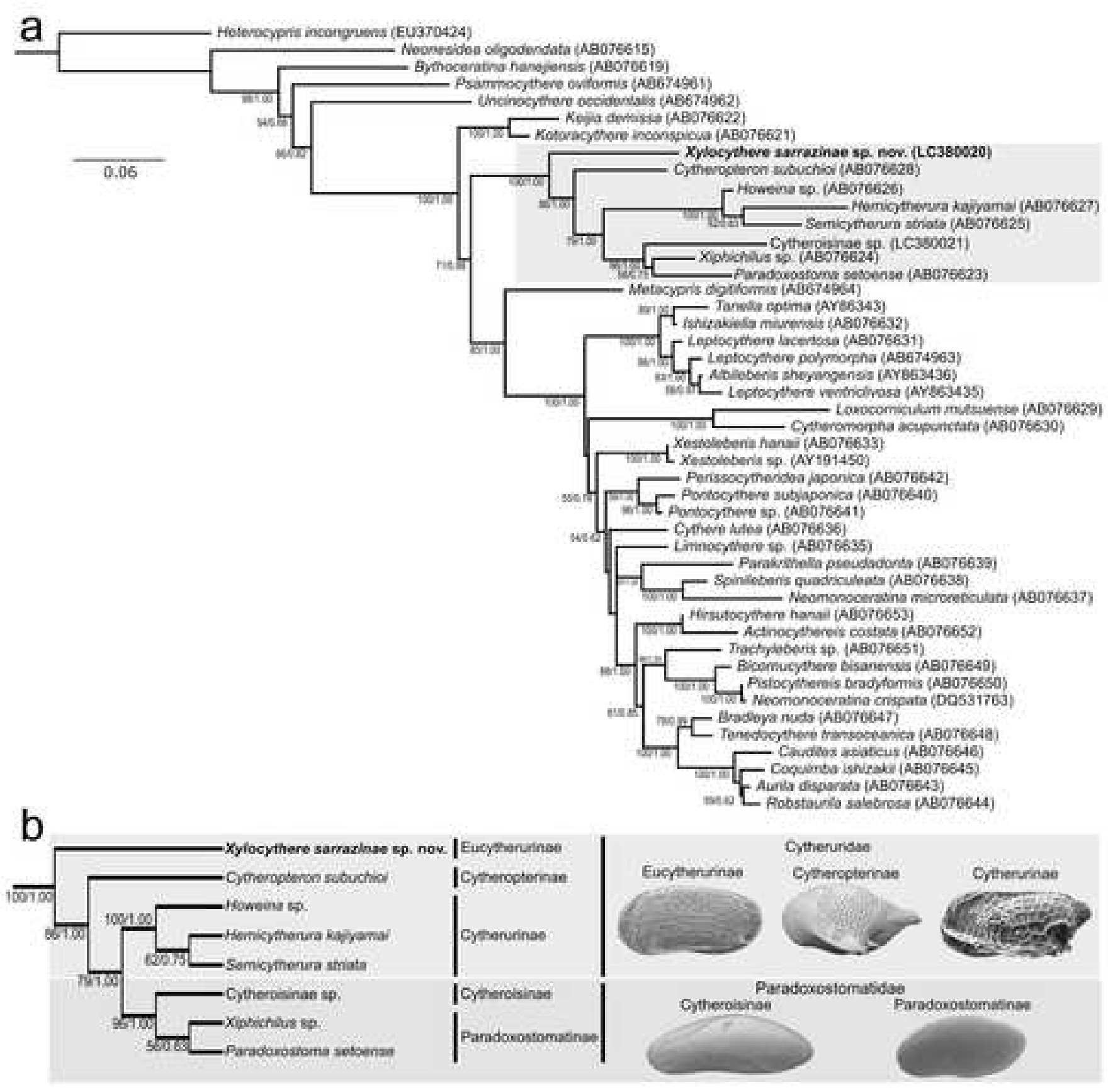




\begin{tabular}{|c|c|c|c|c|c|c|c|c|c|c|c|}
\hline & Late $\mathrm{E}$ & Late Og & Early M & Middle M & Lare M & Eearly Ps & Late Ps & $\mathrm{H}$ & $\begin{array}{c}\text { Recent } \\
\text { HV }\end{array}$ & $\begin{array}{c}\text { Recent } \\
\text { WF }\end{array}$ & References \\
\hline Xylocythere trunerae Maddocks and Steineck, 1987 & & & & & & & & & & $1,2,3$ & Maddocks and Steineck (1987) \\
\hline X.pointillissima Maddocks and Steineck, 1987 & & & & & & & & & & $1,2,3$ & Maddocks and Steineck (1987) \\
\hline X. rimosa Maddocks and Steineck, 1987 & & & & & & & & & & 4 & Maddocks and Steineck (1987) \\
\hline X.tridentis Maddocks and Steineck, 1987 & & & & & & & & & & 1 & Maddocks and Steineck (1987) \\
\hline X. sarrazinae sp. nov. & & & & & & & & & 5 & & This study \\
\hline X. vanharteni Maddocks, 2005 & & & & & & & & & 6 & & Van Harten $(1992,1993)$; Maddocks (2005) \\
\hline X. producta (Colalongo and Pasini, 1980) & & & & 7,9 & & 8 & & & & & 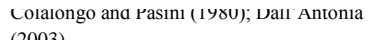 \\
\hline X. carpathica Szczechura, 1995 & & & & 10 & & & & & & & Szczechura $(1995,2000)$ \\
\hline$X$. sp. 1 from Steineck et al. (1990) & & 11 & & & & & & & & & Steineck et al. (1990) \\
\hline$X$. sp. 2 from Steineck et al. (1990) & & & & 12 & & & & & & & Steineck et al. (1990) \\
\hline$X$. sp. 3 from Steineck et al. (1990) & & & & & & & & 13 & & & Steineck et al. (1990) \\
\hline$X$. sp. 4 from Steineck et al. (1990) & & & & & & & & 13 & & & Steineck et al. (1990) \\
\hline$X$. sp. 5 from Steineck et al. (1990) & & & & & 11 & & & & & & Steineck et al. (1990) \\
\hline$X$. sp. 6 from Steineck et al. (1990) & & & & & & & & 13 & & & Steineck et al. (1990) \\
\hline X. sp. 7 from Steineck et al. (1990) & & & 14 & & & & & & & & Steineck et al. (1990) \\
\hline$X$. sp. from Corrège (1993) & & & & & & & & 15,16 & & & Corrège (1993) \\
\hline$X$. sp. from Kiel and Goedert (2006) & 17 & & & & & & & & & & Kiel and Goedert (2006) \\
\hline$X$. sp. from Bergue and Coimbra (2008) & & & & & & & 18 & & & & Bergue and Coimbra (2008) \\
\hline$X$. sp. from Yasuhara et al. (2009) & & & & & & & & 19 & & & Yasuhara et al. (2009) \\
\hline$X$. sp. from Machian-Castillo et al. (2014) & & & & & & & & 20 & & & Machian-Castillo et al. (2014) \\
\hline
\end{tabular}


Table 2. Dimension of valves of Xylocythere sarrazinae sp. nov. from the type locality.

\begin{tabular}{llccccccc}
\hline & & \multicolumn{3}{c}{ Length $(\mu \mathrm{m})$} & & \multicolumn{3}{c}{ Height $(\mu \mathrm{m})$} \\
\cline { 3 - 4 } \cline { 8 - 9 } & & Mean & Observed range & $N$ & & Mean & Observed range & $N$ \\
\hline \multirow{2}{*}{ Male } & RV & 542 & $528-549$ & 7 & & 257 & $247-263$ & 7 \\
& LV & 542 & $530-556$ & 6 & & 262 & $254-267$ & 6 \\
\hline \multirow{2}{*}{ Female } & RV & 557 & $541-576$ & 12 & & 272 & $266-280$ & 12 \\
& LV & 555 & $538-578$ & 10 & & 277 & $270-284$ & 10 \\
\hline
\end{tabular}




\section{Zoobank registration number of new species}

urn:1sid:zoobank.org:act:66E0D33D-CAB8-4C4F-8758-D7E95A7CAC69

\section{Data availability statement}

Sequence data of Xylocythere sarrazinae sp. nov. that support the findings of this study have been deposited in GenBank with the accession codes LC380020 (https://www.ncbi.nlm.nih.gov/nuccore/LC380020.1) 